\title{
Regional growth in Mexico under trade liberalisation: how important are agglomeration and FDI?
}

\author{
Jacob A. Jordaan · Eduardo Rodriguez-Oreggia
}

Received: 11 November 2009 / Accepted: 14 August 2010 / Published online: 5 September 2010 (C) The Author(s) 2010. This article is published with open access at Springerlink.com

\begin{abstract}
The opening of the Mexican economy in the late 1980s has generated increasing levels of inward foreign direct investment (FDI) as well as substantial changes in the location pattern of economic activity within Mexico. Although these developments have coincided with marked changes in Mexico's regional growth regime, previous research has focused mainly on identifying growth effects from regional endowments of physical and human capital. In this paper, we extend on this research by conducting empirical analysis that centers explicitly on identifying the regional growth effects from agglomeration and FDI. The main findings of our analysis are threefold. First, we find that both agglomeration and FDI have acted as important drivers of regional growth in the last two decades. Second, both phenomena can be linked to the materialization of both positive and negative growth effects. The variety of growth effects that we identify is in line with the locational readjustments of economic activity that have taken place. Third, our estimations also identify clear spatial dimensions to the growth effects from agglomeration and FDI; furthermore, these spatial growth effects represent an important component of the overall spatiality of the regional growth process in Mexico.
\end{abstract}

JEL Classification $\quad \mathrm{O} 47 \cdot \mathrm{R} 11 \cdot \mathrm{F} 23 \cdot \mathrm{N} 96$

\footnotetext{
J. A. Jordaan $(\varangle)$

Department of Economics and Business Administration, Free University of Amsterdam, Amsterdam, The Netherlands e-mail: jjordaan@feweb.vu.nl

E. Rodriguez-Oreggia

EGAP, ITESM Campus State of Mexico, Mexico, DF, Mexico

e-mail: eduardo.oreggia@gmail.com
} 


\section{Introduction}

In line with ideas from endogenous growth theory, research on growth processes at subnational levels is increasingly focusing on the role of externalities in regional growth (Rosenthal and Strange 2004; Schnellenbach and Döring 2006). Two phenomena that are closely linked to regional externalities are the existence of agglomerations of economic activity and the presence of foreign direct investment (FDI). It is well known that economic activity shows a persistent tendency to concentrate geographically in space (Henderson et al. 2001). By doing so, firms can generate agglomeration economies, representing productivity advantages in the form of externalities that are directly linked to the existence of the agglomeration (Marshall 1890). Through channels such as search and match externalities on input and labour markets and the occurrence of knowledge spillovers, agglomeration economies are generated that place firms in the agglomeration at a productivity advantage over firms located elsewhere (Duranton and Puga 2004; Eberts and McMillen 1999). As for FDI, the presence and operations of foreign-owned firms can also be linked to externality effects, where channels including competition effects, demonstration effects and input-output linkages generate productivity improvements or spillovers among domestic firms in a host economy (Blomström and Kokko 1998; Caves 2007; Lipsey 2004). Recent empirical research on FDI spillovers has started to estimate regional dimensions of these effects and provides indications that FDI spillovers may be particularly important at sub-national levels (Driffield et al. 2004; Blalock and Gertler 2008; Girma and Wakelin 2007; Jordaan 2009).

Mexico offers a very interesting setting to investigate regional growth effects from both agglomeration and FDI. Following the introduction of policies of economic liberalisation and trade promotion in the late 1980s, the Mexican economy experienced important structural changes. These changes have had distinct spatial dimensions, indicated by the fact that, following a period of increasing regional equalisation, the period of trade liberalisation is characterised by growing regional inequality (Rodriguez-Pose and Sanchez-Reaza 2002). Studies that have looked at factors that have acted as important drivers of regional growth during this period have concentrated on identifying growth effects from regional endowments of physical and human capital (e.g. Rodriguez-Oreggia and Rodriguez-Pose 2004; Rodriguez-Oreggia 2007; Chiquiar 2005). In comparison to this, the role of externalities in these growth processes has received very little attention. The need to analyse the role of externalities in regional growth in this country is underlined by the fact that several new agglomerations of economic activity have developed in the north of Mexico in the last two decades and that there has been a large increase in the level of inward FDI, suggesting that externalities from agglomeration and FDI may have played an important role.

Against this background, the purpose of this paper is to investigate empirically the role of agglomeration and regional FDI in processes of regional growth in Mexico during the period of trade liberalisation. The paper is constructed as follows. In Sect. 2, we discuss in more detail the nature of regional growth in Mexico and look at developments in the location pattern of economic activity and the volume and type of regional FDI. Section 3 discusses the dataset and variables that we use in our empirical analysis. Section 4 presents our main findings, which can be summarised as follows. 
First, our estimations provide strong evidence that both agglomeration and regional FDI have acted as important drivers of regional growth. Second, agglomeration and FDI can be linked to several growth effects of a positive and negative nature. Third, our analysis identifies spatial dimensions to the growth effects from both agglomeration and FDI, whereby our findings also suggest that the spatial growth effects from these two phenomena constitute a major component of the overall spatiality of regional growth in Mexico. Finally, Sect. 5 summarises and discusses policy implications of our findings.

\section{Trade liberalisation, regional growth, agglomeration and FDI}

Following the boom in oil revenues in the 1970s, the Mexican economy was hit hard by the decrease in oil prices in the 1980s, creating a situation where Mexico became unable to make interest payments on its international loans (Cardenas 1996). In response to this crisis, Mexico radically changed its development strategy, substituting policies of economic liberalisation and trade promotion for import substitution and government intervention (ten Kate 1992; Cardenas 1996; Hanson 1997). This change in development strategy resulted in a drastic change in the nature of regional growth. Regional growth in the period of import substitution was characterised by absolute convergence (Juan Ramon and Rivera-Batiz 1996; Rodriguez-Pose and SanchezReaza 2002; Rodriguez-Oreggia 2005). The opening up of the Mexican economy led to a switch in the regional growth regime towards absolute divergence (Chiquiar 2005), favouring in particular states in the north of Mexico (Aroca et al. 2005). This change in the development of regional inequality is shown in Fig. 1. This figure presents the development of regional inequality in Mexico for the period 1970-2004, measured as the standard deviation of regional per capita output of the Mexican states. Up until the end of the 1980s, the level of regional disparity decreases. Then, following the change in development strategy, the level of regional inequality increases steadily up until the late 1990s. In the early 2000s, the level of regional inequality appears to be stabilising.

Empirical research on regional characteristics that have acted as important drivers of regional growth during the period of trade liberalisation have tended to focus on "traditional" factors in the form of regional endowments of production inputs. In particular, Rodriguez-Pose and Sanchez-Reaza (2002); Rodriguez-Oreggia (2007) and Esquivel and Messmacher (2002) find that the regional endowment of human capital is positively associated with growth rates of regional GDP per capita. Gonzalez Rivas (2007) and Chiquiar (2005) present further findings that identify regional infrastructure and physical capital as other important growth factors. ${ }^{1}$ The findings from these studies also indicate that the materialisation of regional divergence during the period of trade liberalisation has been at the advantage of states in the north of Mexico in particular, states that share a border with the US. The explanation for this is that these states, together with Mexico City, were particularly well endowed with these regional production inputs that became increasingly important drivers of regional growth.

\footnotetext{
${ }^{1}$ Rodriguez-Oreggia and Rodriguez-Pose (2004) present findings of an insignificant growth effect from regional public infrastructure, however.
} 


\subsection{Agglomeration and FDI}

Two important features of the period of trade liberalisation have been the large increase in the level of inward FDI and the drastic changes in the location pattern of economic activity. To indicate the extent to which the level of foreign participation in the Mexican economy has increased, during the 1990s the level of inward FDI more than doubled (Pacheco-Lopez 2005; Jordaan 2008a). Also, the value of inward FDI stock as percentage of total GDP increased from 8.5\% in 1990 to over 27\% in 2006 (see UNCTAD 2007). As for the Maquiladora program, in which FDI firms participate that focus on labour-intensive assembly activities, its size has also increased markedly: whereas in 1980 about $5.5 \%$ of the Mexican labour force in the manufacturing sector was employed by Maquiladora firms, in 2006 this had increased to $26 \%$ (Jordaan 2009).

Tables 1 and 2 present indicators of the main spatial changes that have occurred in the Mexican economy following the introduction of trade liberalisation. Table 1 shows employment shares of Mexico City, the border states and the group of other states in the manufacturing sector, Table 2 contains indicators of the regional distribution of FDI. Looking first at employment shares, Mexico City has experienced a strong decrease in its level of participation in manufacturing activity. During the period of import substitution, Mexico City had rapidly become the prime location for manufacturing firms (Krugman and Livas-Elizondo 1996). To indicate the speed and scale of the level of agglomeration in the centre of the country, during the period 19301960 the share of Mexico City in total manufacturing increased from $19 \%$ to almost

Table 1 Regional employment shares, 1980-2003

\begin{tabular}{|c|c|c|c|c|c|c|c|c|c|c|}
\hline & \multicolumn{5}{|c|}{$\%$ Share in manufacturing employment } & \multicolumn{5}{|c|}{$\%$ Share in employment sector 38} \\
\hline & 1980 & 1985 & 1993 & 1998 & 2003 & 1980 & 1985 & 1993 & 1998 & 2003 \\
\hline Mexico City & 44.4 & 36.8 & 29 & 23 & 21 & 51 & 40 & 26 & 18 & 15 \\
\hline Border states & 21 & 23 & 30 & 35 & 35 & 27 & 34 & 50 & 58 & 59 \\
\hline Other states & 34.6 & 40 & 41 & 42 & 44 & 22 & 26 & 24 & 24 & 26 \\
\hline
\end{tabular}

Sources: regional employment shares taken from Hanson (1997) and Economic Census (various years) Mexico City Federal District and State of Mexico, border states Baja California, Coahuila, Chihuahua, Nuevo Leon, Sonora and Tamaulipas

Table 2 Regional FDI inflows and Maquiladora employment; 1989-2004

\begin{tabular}{lllllllr}
\hline & \multicolumn{2}{l}{$\%$ Share in FDI inflows } & & \multicolumn{2}{c}{ \% Share in Maquiladora employment } \\
\cline { 2 - 3 } & $1989-1993$ & $1994-1999$ & $2000-2004$ & & 1992 & 1996 & 2004 \\
\hline Mexico City & 67.3 & 58.5 & 65.5 & & 0.6 & 0.9 & 0.5 \\
Border states & 12.2 & 30.6 & 24.2 & & 91.7 & 87 & 83.1 \\
Other states & 20.5 & 10.9 & 10.3 & & 7.7 & 12.1 & 16.4 \\
\hline
\end{tabular}

Sources: Regional FDI inflows based on data provided by Secretaria de Economia and Jordaan (2008a); regional employment shares in maquiladora industries based on data in INEGI (2000) and Jordaan (2009) Mexico City Federal District and State of Mexico, border states Baja California, Coahuila, Chihuahua, Nuevo Leon, Sonora \& Tamaulipas 
50\% (Hanson 1997). This dominance of Mexico City has weakened substantially in the last two decades. As Table 1 shows, in less than 25 years Mexico City has seen its employment share more than halved. In contrast to this development, the border states have clearly benefited from the opening up of the Mexican economy, indicated by the substantial increase in their employment share. These spatial changes are most striking when we look at sector 38 , which contains modern industries including the production and assembly of cars and car parts, televisions and computers. The border states have come to incorporate almost $60 \%$ of total employment in these industries, four times larger than the share of Mexico City.

The main reason for these strong locational changes of manufacturing industries is that the opening up of the Mexican economy made the US the new main market for many firms and industries (Hanson 1998a; Krugman and Livas-Elizondo 1996; Jordaan and Sanchez-Reaza 2006). ${ }^{2}$ As a result of this shift in the location pattern of industries, the distribution of economic activity in Mexico has changed from a situation where there was one main agglomeration of economic activity in and around Mexico City to a situation where the majority of manufacturing activity is agglomerated in a limited number of production centres in the north and centre of the country.

Table 2 presents the main developments of FDI in Mexican regions. Mexico City constitutes the region with the largest level of inward FDI, receiving over $60 \%$ of total FDI inflows. The border states have become a much more important location for new FDI activity, indicated by the increase in their share in inward FDI flows to more than $30 \%$ at the end of the 1990s. The group of remaining states has seen their share in inward FDI flows halved. The regional distribution of Maquiladora FDI further indicates the importance of the border states as location for FDI. One explanation for the dominance of the border states as location for Maquiladora firms is that these states were earmarked originally as main location for these firms. The lifting of locational restrictions of this type of FDI during the 1990s has not led to a substantial change in the location pattern of these firms, however. Of course, proximity to the US, constituting the main source of inputs and the main destination market for assembled products, constitutes the main motivation for Maquiladora firms to locate in Mexico's border states. ${ }^{3}$

Summing up, the introduction of trade liberalisation has generated important changes in the Mexican economy. One of these changes has been an increasing level of regional inequality, favouring in particular states located in the north of Mexico. At the same time, the period of trade liberalisation is characterised by growing levels of inward FDI and substantial changes in the location pattern of manufacturing activity. In essence, the majority of economic activity has come to be agglomerated in a limited number of production centres in the north and centre of the country. The growing levels of inward FDI also show a tendency to concentrate in these regions. In combination, these developments suggest that it is very likely that agglomeration and

\footnotetext{
2 See Hanson (1997, 1998b), Jordaan and Sanchez-Reaza (2006) and Faber (2007) for statistical evidence on the importance of proximity to markets for regional employment growth.

3 There is evidence from recent years that some Maquiladora activity is locating further away from the border with the US, indicated by the increase in the Maquiladora employment share of the group of other states in Table 2. This concerns in particular the states of Jalisco, Yucatan, Durango and Puebla, which have experienced an increase in Maquiladora activity mainly in the industries of textiles and leather (see Jordaan 2008a).
} 


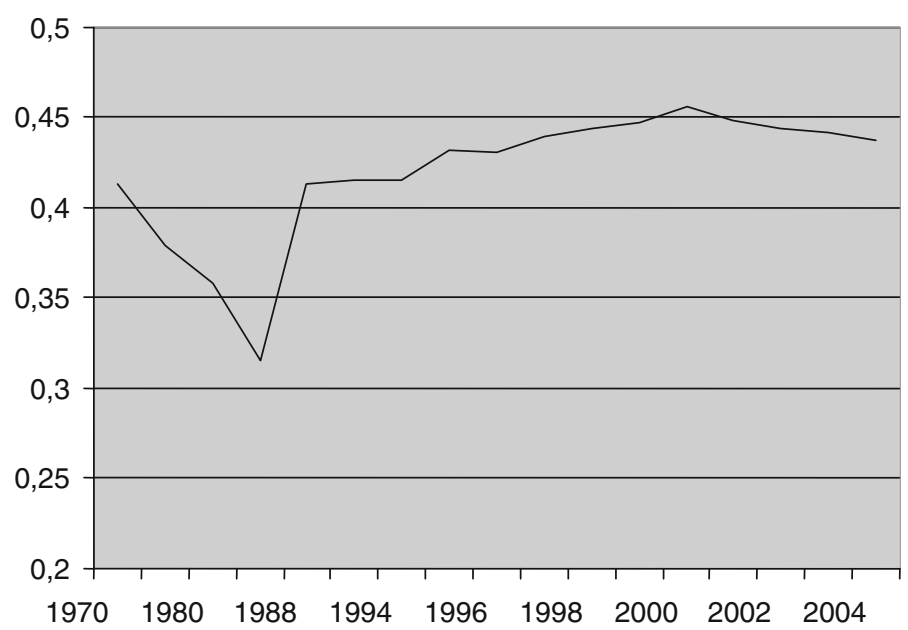

Fig. 1 Disparity Regional GDP/Capita 1970-2004. Source: own calculations based on data provided by INEGI. Note: Campeche and Tabasco are omitted, as their income is heavily inflated by the presence of oil industries. Regional disparity calculated as the standard deviation of real per capita output ( $\sigma$ convergence, see Barro and Sala-i-Martin 1995)

regional FDI have played an important role in processes of regional growth following the introduction of trade liberalisation. This has not been analysed in previous research on regional growth however, which has focused instead on identifying statistically the presence of absolute convergence and divergence and on the role of regional endowments of physical and human capital. In response to this gap in the literature, in the next sections we present an empirical study on drivers of regional growth in Mexico in the last two decades, whereby we focus in particular on identifying and assessing the roles of agglomeration and regional FDI.

\section{Data and regression model}

To identify the growth effects from agglomeration and regional FDI, we conduct conditional convergence growth regressions. The concept of absolute convergence refers to the expectation that, in a neo-classical framework, regions in a country that start at a level below their steady state growth will experience per capita output growth at a higher rate compared to other regions (Barro 1991; Barro and Sala-i-Martin 1995). As mentioned earlier, evidence from previous studies on Mexico indicates the presence of absolute convergence during the period of import substitution and absolute divergence following the introduction of trade liberalisation (Juan Ramon and Rivera-Batiz 1996; Chiquiar 2005; Rodriguez-Oreggia 2005; Rodriguez-Pose and Sanchez-Reaza 2002). The drawback of this evidence is that it is based on the unrealistic assumption that all regions in Mexico share the same steady state per capita output level. To identify the regional growth regime, whilst controlling for differences in steady state output between states, conditional convergence estimations are more appropriate. For our study, this gives: 


$$
\begin{aligned}
\frac{1}{T}\left(\log \left(\frac{Y(i)(t+1)}{Y(i) t}\right)\right)= & \alpha+\beta \log Y(i) t+\beta X(i) t+\beta \text { Agglomeration }(i) t \\
& +\beta \mathrm{FDI}(i) t+\varepsilon(i) t
\end{aligned}
$$

$t=1,2,3$ (periods)

(i) $=1,2, \ldots . .30$ (states)

where $T$ is the number of years in period $t, Y(i) t$ is regional per capita GDP at the start of period $t$ in state $i$ and $Y(i)(t+1)$ is per capita GDP at the beginning of period $t+1$. The estimated sign of the $\beta$-coefficient of GDP per capita at the begin year of the period captures the presence of conditional convergence or divergence. Vector $X(i) t$ contains several state characteristics that have been identified by previous research to influence regional growth. Agglomeration $(i) t$ and $\mathrm{FDI}(i) t$ contain variables capturing several aspects of agglomeration and regional FDI. As for the units of observation and time periods, we collected state level data for the periods 1988-1993, 1994-1998 and 1999-2004. The choice of these periods is driven by data availability considerations. In Mexico, a country-wide census is carried out at 5 to 6 -year intervals. The base years of the periods that we use concern the years of publication of these censuses, which represent the best source of regional economic data in Mexico. Following previous research, we omit the outlier oil states Campeche and Tabasco from the dataset, giving a total of 90 observations. ${ }^{4}$

Vector $X$ contains the following variables. We control for human capital by including a variable labelled SCHOOL which captures the average number of years of schooling of the regional economic active population. To capture the effect of the increase in the skill premium that appears to have occurred in the border states (see Feenstra and Hanson 1997), we follow Chiquiar (2005) by adding an interaction variable labelled SCHOOL*BORDER. Infrastructure is captured by the variable TELEPHONES, measured as the number of telephone connections per 100 persons. The share of agriculture in regional GDP labelled AGRICULTURE is included to control for the negative effect of a large regional reliance on agricultural activities for the development of manufacturing activity. We also control for the regional variation of state investment by including STATE_EXP, which is the ratio of total state expenditure over regional GDP. Finally, we add a dummy variable for the period 1999-2004, given the finding in Fig. 1 that the growth of regional inequality appears to have levelled of during the early 2000 s.

Next, we need to control for the presence of agglomeration economies. One interpretation of agglomeration economies is that the scale of a regional industry or the size of total regional economic activity is related to the volume of these regional externalities (see Moomaw 1988; Eberts and McMillen 1999; Hanson 2001). Following this interpretation, a large regional industry will generate more positive externalities than a small regional industry, which would show up as an estimated positive association between regional growth and regional industry size. In our regression model, we distinguish between agglomeration economies from manufacturing and regional externalities that are related to the scale of total regional economic activity, by

\footnotetext{
4 See the appendix for definitions and datasources, summary statistics and correlation matrix.
} 
estimating for the growth effects of the regional number of manufacturing employeesMANUFACTURING - and of regional population size-POPULATION ${ }^{5}$

An important potential drawback of the use of such scale variables is that they may contain endogenous elements and/or be correlated with other explanatory variables. This is recognised by Ciccone and Hall (1996), who propose to use the level of density of manufacturing industries and of total regional economic activity as alternative indicators of agglomeration economies (see also Ciccone 2002; Glaeser and Gottlieb 2009). A regional industry that is characterised by a high level of density (a high level of geographical proximity between firms) is likely to have more frequent contacts and exchanges between firms, resulting in a higher level of interconnectedness and knowledge spillovers (see also Storper and Venables 2004). Therefore, we also estimate the regression model with these alternative indicators of agglomeration economies in the form of the regional level of density of manufacturing-MANDENSITY —and total economic activity-POPDENSITY.

Finally, we use several variables to control for regional growth effects that are related to the level and type of regional FDI. One variable that we use is the ratio of total regional inward FDI flows over regional GDP, labelled FDIFLOWS/PIB. This variable captures the overall growth effect from foreign capital investment. ${ }^{6}$ Second, we include a FDI-stock variable labelled FORMAN, measured as the share of foreign-owned manufacturing firms in regional manufacturing employment. In line with research on FDI spillovers, we interpret this variable as capturing the presence of regional FDI externalities (Driffield et al. 2004; Girma and Wakelin 2007). It is not clear what type of effect to expect from this variable a priori. Cross-sectional evidence based on national level manufacturing industry data for 1993 suggests the presence of positive intra-industry FDI spillovers (Jordaan 2005, 2010). ${ }^{7}$ In contrast, evidence based on more aggregated cross-sectional data for regional industries suggests that FDI firms may be generating both positive and negative productivity effects (Jordaan 2008b). ${ }^{8}$ In addition to this FDI stock variable, we also control for the regional growth effect generated by the large dominance of Maquiladora FDI in the border states. We do so by adding a variable labelled MAQUILA*BORDERDUMMY, which is an interaction variable between the regional number of Maquiladora employees and a border states dummy.

\footnotetext{
5 Empirical studies on agglomeration economies usually distinguish between localization and urbanization economies (Eberts and McMillen 1999). Localisation economies are externalities that are internalized within regional industries, whereas urbanization economies are regional externalities that are internalized only at the aggregate regional level. In our estimations, we also try to make such a distinction, by estimating for separate agglomeration economies from manufacturing and from total regional economic activity. The reason for separating out agglomeration economies from manufacturing is that manufacturing firms in particular have responded to the opening up of the Mexican economy by locating in the north of Mexico. Also, the majority of the substantially increased level of inflows of new FDI has consisted of FDI investments creating new manufacturing firms (see Jordaan 2009).

6 This concerns total regional FDI in all sectors.

7 Similar findings based on cross-sectional data for 1970 are presented by Blomström and Persson (1983) and Blomström and Wolff (1994).

8 See also Jordaan (2008c).
} 


\section{Empirical findings}

\subsection{Agglomeration and FDI as drivers of regional growth}

The findings from estimating several specifications of regression model (1) are presented in Table 3. The first column presents the results from a feasible generalised least squares (FGLS) estimation that allows for correlated errors between panels, similar in spirit to Chiquiar (2005), omitting agglomeration and FDI variables. The estimated coefficient of initial GDP per capita carries an insignificant coefficient, suggesting the absence of divergence or convergence. The variables of infrastructure, agriculture and the 1998 dummy carry significant coefficients with expected signs. The estimated effect of schooling is insignificant, which is contrary to expectations. Having said this, the literature shows that the estimated effect of schooling is often insignificant or even negative (Pritchett 2001; Barro and Sala-i-Martin 1995; Gonzalez Rivas 2007). The estimated effect of the skill premium in the border states also fails to reach significance.

The second column presents the findings from a panel data estimation that allows for heteroscedasticity and autocorrelation. The assumption in the FGLS estimation that panels can only be related via their errors is very restrictive, especially in the

Table 3 Drivers of regional growth in Mexico, 1988-2004

\begin{tabular}{|c|c|c|c|c|c|}
\hline & 1 & 2 & 3 & 4 & 5 \\
\hline Constant & $0.14(0.12)$ & $0.09(0.08)$ & $0.38(0.10) \mathrm{a}$ & $0.30(0.08) \mathrm{a}$ & $0.09(0.08)$ \\
\hline Initial GDP & $-0.032(0.021)$ & $-0.038(0.009) \mathrm{a}$ & $-0.04(0.011) \mathrm{a}$ & $-0.05(0.011) \mathrm{a}$ & $-0.038(0.009) \mathrm{a}$ \\
\hline School & $-0.03(0.04)$ & $-0.03(0.02)$ & $-0.12(0.03) \mathrm{a}$ & $-0.08(0.006) \mathrm{a}$ & $-0.027(0.024)$ \\
\hline Telephones & $0.019(0.009) \mathrm{a}$ & $0.013(0.005) \mathrm{a}$ & $0.036(0.006) \mathrm{a}$ & $0.032(0.005) \mathrm{a}$ & $0.013(0.005) \mathrm{a}$ \\
\hline Agriculture & $-0.011(0.006) b$ & $-0.019(0.003) \mathrm{a}$ & $-0.013(0.003) \mathrm{a}$ & $-0.02(0.003) \mathrm{a}$ & $-0.019(0.003) \mathrm{a}$ \\
\hline State exp & $-0.0009(0.001)$ & $0.002(0.003)$ & $0.002(0.003)$ & $-0.0002(0.001)$ & $0.002(0.001)$ \\
\hline 1998 dummy & $0.024(0.003) \mathrm{a}$ & $0.019(0.004) \mathrm{a}$ & $0.007(0.006)$ & $0.009(0.004) \mathrm{b}$ & $0.019(0.004) \mathrm{a}$ \\
\hline School*border & $-0.002(0.002)$ & $-0.003(0.001) \mathrm{a}$ & $0.0003(0.0005)$ & $-0.0001(0.0004)$ & $-0.003(0.0015) b$ \\
\hline Manufacturing & & & $0.045(0.044)$ & & \\
\hline Population & & & $-0.01(0.006) \mathrm{c}$ & & \\
\hline Man density & & & & $0.008(0.003) \mathrm{b}$ & $0.009(0.002) \mathrm{a}$ \\
\hline Pop density & & & & $-0.015(0.003) \mathrm{a}$ & $-0.015(0.003) \mathrm{a}$ \\
\hline FDIflows/Pib & & & & & $0.03(0.007) \mathrm{a}$ \\
\hline $\begin{array}{l}\text { Maquila } \\
\text { *Borderdummy }\end{array}$ & & & & & $0.003(0.0015) \mathrm{b}$ \\
\hline Forman & & & & & $-0.005(0.001) \mathrm{a}$ \\
\hline Walch $\chi^{2}$ & $58.75(0.00)$ & $92.81(0.00)$ & $114.67(0.00)$ & $136.87(0.00)$ & $160.53(0.00)$ \\
\hline$R^{2}$ & n.a.** & 0.56 & 0.62 & 0.65 & 0.71 \\
\hline$N$ & 90 & 90 & 90 & 90 & 90 \\
\hline
\end{tabular}

Estimated standard errors in parentheses

$a, b$ and $c$ significance levels at 1, 5 and 10\%, Column 1 FGLS controls for correlation of errors between panels, columns 2-5 control for correlation of errors between panels, autocorrelation and heteroscedasticity ** Regression (1) concerns FGLS, which gives an unusable $R^{2}$ statistic, as it does not represent the percentage of variation of the dependent variable that is accounted for by the model 
case of repeated observations through time. The findings from the estimation that controls for heteroscedasticity and autocorrelation differ from the original findings in two important respects. First, the estimated effect of initial regional GDP per capita becomes significant and negative, indicating the presence of conditional convergence among the Mexican regions. Second, the estimated effect of the skill premium in the border states also carries the expected significant negative sign.

The third and fourth columns contain the findings from adding the agglomeration variables to the regression model. The results in the third column contain only very modest evidence for the presence of agglomeration economies. The estimated growth effect of the scale of regional manufacturing is insignificant, suggesting the absence of agglomeration economies from this source. The estimated effect of regional population is negative and mildly significant, indicating the presence of negative agglomeration economies from the scale of total regional economic activity. The findings with the density scores of manufacturing and total economic activity contain much stronger indications of the presence of regional externalities, shown in column 4 . The level of density of regional manufacturing carries a significant and positive sign, indicating that regions with a relative high level of geographical proximity between manufacturing firms grow faster. In contrast, the estimated effect of the level of density of total regional economic activity is negative, indicating that regions with a high level of density of overall economic activity suffer from negative congestion costs.

Of course, there is the issue of endogeneity or causality here. Agglomeration may influence regional growth, but regional growth may also affect regional agglomeration. One reason why we belief that this issue is not too problematic for the present analysis is that even if growth enhances the scale of agglomeration, this does not automatically mean that growth influences the level of density of regional activity. Furthermore, it is important to consider what the main driving force behind agglomeration of economic activity is. The opening up of the Mexican economy has made the states bordering with the US an attractive location for many firms and industries. Therefore, the motivation for most firms to locate in the north of Mexico has not been related to growth rates of these states, but rather to the fact that these states are in close proximity to the new international market in the form of the US. As a result of this, agglomerations have developed in these states with favourable effects on regional growth, suggesting that the line of causation runs from agglomeration to regional growth.

To see whether endogeneity has affected our estimations, and in the absence of other suitable instruments, we can estimate the regression model using lagged values for both the agglomeration density variables. ${ }^{9}$ Both variables maintain to carry significant coefficients with similar signs, further supporting the finding from the full sample that agglomeration generates significant positive and negative growth effects. ${ }^{10}$ In addition

\footnotetext{
9 This means that we link the agglomeration variables of 1988 with average regional growth for the period 1993-1998 and agglomeration of 1993 with average regional growth for the period 1998-2004.

10 Lagged Mandensity has a coefficient of 0.004 ( $p$ value $=0.03$ ), lagged Popdensity has a coefficient of -0.012 ( $p$ value $=0.01$ ). We also estimated the model with lagged agglomeration scale variables. The results of that estimation are lagged manufacturing with a coefficient of 0.013 ( $p$ value $=0.01$ ) and lagged population with a coefficient of $-0.018(p$ value $=0.02)$.
} 
to these estimations, we also perform an augmented Durban-Wu-Hausman (DWH) test to assess whether there are endogenous relationships between regional growth and the two agglomeration variables. We do so by regressing either Mandensity or Popdensity on the other control variables. We then add the residuals from these regressions to the original regression model; if these residuals carry a significant coefficient in the second stage regression, there is likely to be a problem of endogeneity (see Hausman 1978; Li and Lui 2005; Jordaan 2010). The findings from this exercise show that the residuals from the first stage regression with Mandensity as dependent variable do not carry a significant coefficient. The residuals with Popdensity as dependent variable do, however, suggesting that there is an endogenous component in the relation between regional growth and Popdensity. ${ }^{11}$ This does not pose too much of a problem for our analysis. Under the assumption that the effect of regional growth on Popdensity is positive, we can interpret the magnitude of the estimated negative association between Popdensity and regional growth in Table 3 as a lower bound of this effect. In other words, as the estimated association between Popdensity and regional growth captures simultaneously both the positive effect of regional growth on Popdensity and the negative effect of Popdensity on regional growth, the presence of endogeneity only means that the real magnitude of the negative effect of Popdensity on regional growth is even larger than we find in our estimations.

Column 5 presents the findings from adding the regional FDI variables to the model. The estimated positive effect of regional FDI indicates the positive overall growth effect from this type of capital investment. Second, the effect of the FDI stock variable in the form of the share of FDI in regional manufacturing employment is negative. This finding is in line with findings from studies on other host economies that identify negative associations between regional FDI and productivity of domestic firms (e.g. Driffield et al. 2004). Findings of negative FDI spillovers are usually explained by the occurrence of a negative market stealing effect (Aitken and Harrison 1999). This effect entails that foreign-owned firms take part of the market share from domestic firms. If the production of these domestic firms is subject to increasing returns to scale, the decrease in production volume will result in decreased efficiency among these firms. Another explanation for the estimated negative effect of the level of foreign participation in regional manufacturing is that FDI firms can drive up prices of regional labour and other inputs. This would also hurt efficiency levels of Mexican firms, resulting in lower regional growth. Finally, the estimated effect of the interaction variable between the border states dummy and the presence of Maquiladora FDI is positive, capturing the positive growth effect that is linked to the large concentration of this type of FDI in the north of Mexico. ${ }^{12}$

Again, we believe that the issues of causality and endogeneity do not restrict our analysis. Considering the line of causation between regional FDI and regional growth,

\footnotetext{
11 Results not reported, available upon request.

12 Maquiladora firms are less likely to generate negative regional externalities. As Maquiladora firms produce predominantly for international markets, they will not generate negative market stealing effects among Mexican firms. Furthermore, Maquiladora firms use very little local material inputs and are characterised by a strong reliance on low wage labour (Ramirez 2003), suggesting that their impact on regional input prices will be limited.
} 
we can make an argument similar to the one we made regarding the line of causation between agglomeration and growth. As the main motivation for FDI firms to locate in the north of Mexico (containing the fast growing regions) has been to be in proximity to the US, rather than to be in regions with relative high growth rates, it is likely that the line of causation between FDI and regional growth runs from the former to the latter. This argument is supported by findings from two recent empirical studies on FDI location in Mexican regions. Jordaan (2008a) estimates regression models to identify regional characteristics that influence regional flows of FDI and finds that regional GDP does not have a robust association with increases in regional inward FDI, especially in the case of Maquiladora FDI. Jordaan 2009 performs conditional logit regressions to identify location factors that have influenced location decisions of a large set of new foreign-owned manufacturing firms in the second part of the 1990s and similarly finds that regional GDP does not have a robust positive effect.

We re-estimate the regression model using lagged values for the FDI variables. The variables FDIflows/PIB and regional Maquiladora maintain to be positively associated with regional growth. The lagged FORMAN variable is now also positively associated with regional growth, which is in contrast to the original findings. ${ }^{13}$ This may indicate that FDI manufacturing firms are attracted to fast growing regions, suggesting that there is a bi-directional line of causation between Forman and regional growth. However, when we conduct a DWH test, there is no evidence that Forman is endogenous. ${ }^{14}$ Therefore, we interpret the switch in sign of the Forman variable that there may be a difference in the short term and long term spillover impact of FDI. In the short term, the presence of FDI may hurt regional growth due to the creation of negative spillovers, caused by a decrease in efficiency among Mexican firms. In the longer term, Mexican firms may be able to respond to the increase in competitive pressure by increasing their efficiency, which would explain the positive effect of lagged FDI on regional growth. There may also be a time dimension at play here, as it may take time for positive FDI spillovers via demonstrations effect or input-output linkages to materialise and surpass the initial negative spillovers.

Looking at the overall set of findings, it is clear that both agglomeration and regional FDI have acted as drivers of regional growth in the last two decades. Having said this, the role of agglomeration economies and FDI seems to be more complex than perhaps envisaged originally, as our estimations also indicate that both phenomena can be linked to both positive and negative growth effects. Importantly, it appears that the presence of both positive and negative growth effects from agglomeration and FDI can be linked to the spatial changes that the Mexican economy underwent following the introduction of trade liberalisation.

During the period of import substitution, economic activity had become heavily concentrated in and around Mexico City. Following the opening up of the Mexican economy, the advantages of locating in the centre of the country diminished, as the US

\footnotetext{
13 Lagged FDIflows/PIB carries a coefficient of 0.017 ( $p$ value $=0.02$ ); lagged FORMAN has a coefficient of 0.002 ( $p$ value $=0.00$ ); lagged Maquila*border has a coefficient of 0.005 ( $p$ value of 0.00 ).

14 The residuals from first stage regressions with either FDIflows/pib, Forman or Maquila*border as dependent variable do not carry significant coefficients in second stage regressions where these residuals are added to the original regression model.
} 
became the new main market for many manufacturing firms and industries (Hanson 1998a). In addition to this pull factor from the northern states, there may also have been a push factor from the old agglomeration in the form of negative externality effects from high rents, wages and congestion costs (Krugman and Livas-Elizondo 1996). Our findings are in support of this explanation, as we find a negative growth effect from density of total regional economic activity. At the same time, new agglomerations of economic activity started to develop in the border region. Our findings indicate a positive growth effect of the level of density of regional manufacturing, suggesting that these new agglomerations in the north of Mexico generate positive agglomeration economies. In combination, these push and pull forces seem to represent an important explanation for the locational changes of economic activity in Mexico.

Furthermore, the growth of the agglomerations of activity in Mexico's northern states has also fostered growing levels of FDI flows into these states, thereby fostering enhanced regional growth and agglomeration. In addition to this general positive relation between agglomeration and regional FDI, the estimated positive growth effect of the interaction variable between the border states dummy and Maquiladora employment indicates that the northern states enjoyed an important further growth stimulus from the large concentration of Maquiladora type investment. The estimated negative effect of the FDI stock variable indicates that the presence of FDI firms also generates negative externalities. This may indicate that the development of indigenous firms has tended to be obstructed by the rapidly growing presence of foreign-owned firms in the north of Mexico, at least as a short run effect, reinforcing the impression that FDI investment in particular has played a major role in the processes of locational readjustment favouring the northern states.

\subsection{Spatial growth effects from agglomeration and FDI}

Our findings indicate that both agglomeration and FDI generate important growth effects at the intra-regional level. These findings do not cover the full potential growth effects of these two phenomena, however, as their growth effects may have spatial dimensions. For instance, it may be the case that a firm benefits from agglomeration economies that arise in a region other than the region where the firm is located. Especially when relating agglomeration economies to the occurrence of knowledge spillovers, the question whether these effects transcend regional borders becomes important (Schnellenbach and Döring 2006; Rodriguez-Pose and Crescenzi 2008; Henderson 2007; Martin 1999; Parr 2002). In a similar fashion, there is no reason to presume that FDI spillover effects are contained at the intra-regional level. In fact, the recent literature on FDI spillovers (Driffield et al. 2004; Girma and Wakelin 2007; Jordaan 2008b, 2009) contain strong indications that such spatial dimensions may be important and in strong need of further empirical verification.

To obtain a good indication of the overall spatiality of the regional growth process we present Fig. 2, which contains Moran scatterplots following Anselin (1988). We plot standardised state level GDP per capita against its standardised spatial lag for 1988 and 1998. Spatially lagged regional GDP for a given state is calculated as the 
weighted share of GDP per capita of those states with which the state shares a border. Below the scatterplots we also report the Moran I statistic that indicates the strength of global spatial autocorrelation of regional GDP per capita. Looking first at 1988, the scatterplot and the Moran I statistic both indicate the presence of significant positive spatial autocorrelation of regional income. The border states are all located in the quadrant of high income states that have high income neighbouring states, suggesting the presence of positive spatial growth effects. Looking at the quadrant containing low income states with low income neighbouring states, it contains most of the states that are located in the south of Mexico, states that reported above average growth rates during the previous period of import substitution. The Moran scatterplot and the Moran I statistic for 1998 indicate that the spatial dimension of regional divergence has clearly persisted during the 1990s.

The hypothesis that we test in this paper with respect to the inter-regional dimension of regional growth is that agglomeration and FDI are both mechanisms that generate spatial growth effects. To test this hypothesis, we need to augment the original regression model with variables that capture potential spatial effects from agglomeration and regional FDI. This gives regression model (2):

$$
\begin{aligned}
\frac{1}{T}\left(\log \left(\frac{Y(i)(t+1)}{Y(i) t}\right)\right)= & \alpha+\beta \log \mathrm{Y}(i) t+\beta X(i) t+\beta \text { Agglomeration }(i) t \\
& +\beta \mathrm{FDI}(i) t+\beta \sum_{i^{\prime}=1 ; i^{\prime} \neq i}^{i} W Z(i) t+\varepsilon(i) t ;
\end{aligned}
$$

where $Z$ contains the spatial growth effects from agglomeration and regional FDI and $W$ is the distance matrix containing spatial weights $w_{\mathrm{ij}}$ which capture the relation between the geographical distance between states $i$ and $j$ and the effects of the variables in $Z$. In our estimations, we distinguish between two spatial effects each from agglomeration and FDI. To capture spatial agglomeration economies, we use the distance-weighted size of regional manufacturing and total regional economic activity. As for regional FDI, one spatial FDI variable is measured as the distance-weighted share of inward FDI in regional GDP. The second FDI variable that we use is the distance-weighted number of regional manufacturing employees working for FDI firms.

As for defining the distance matrix $W$, we experiment with several specifications of the relation between potential spatial effects from agglomeration and FDI and geographical distance, as it is not clear which specification is most appropriate a priori (Anselin 1988; Bode 2004; Harris and Kravtsova 2009). This relates in particular to the assumed potential scale of the geographical reach of the spatial effects. The two most commonly used specifications of the relation between distance and spatial effects are that spatial effects are subject to a geographical cut off point or that spatial effects are negatively related to distance in a continuous fashion. In our analysis, we estimate separate models with spatial variables for both alternative assumptions. We use the first and second order contiguity assumption to capture the existence of a cut off point. With the first order contiguity assumption, spatial effects are assumed to arise only between states that share a border; the $w_{\mathrm{ij}}$ 's are set to 1 when states share a border and 


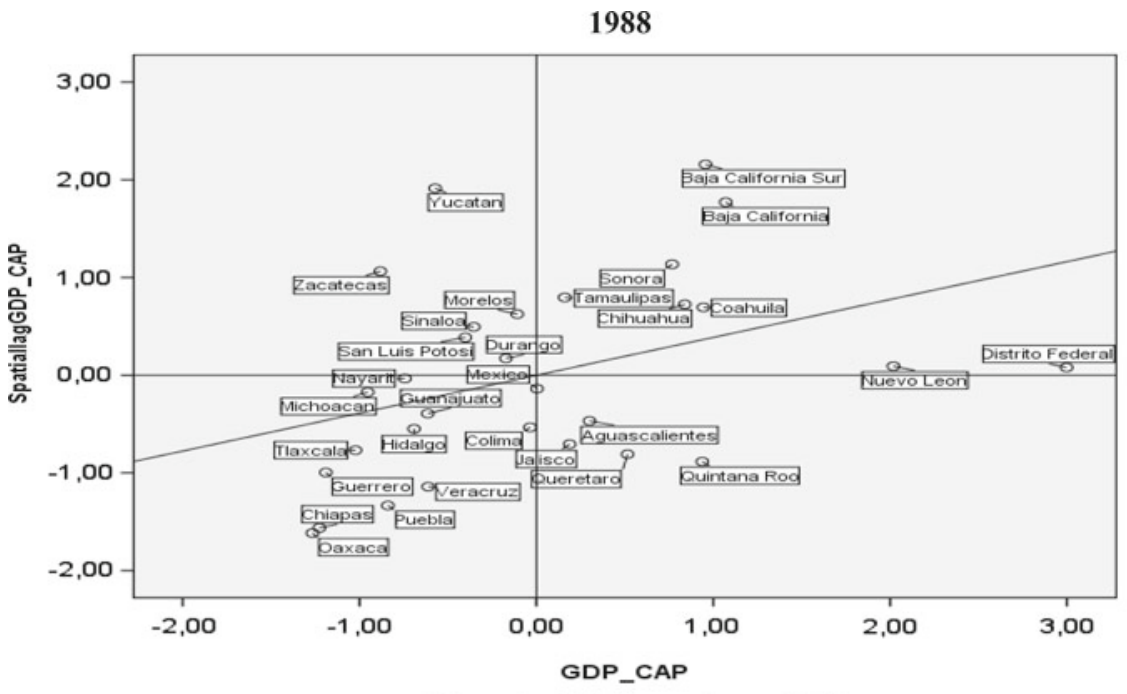

Moran $\mathrm{I}=0.224$, p-value $=0.013$

1998

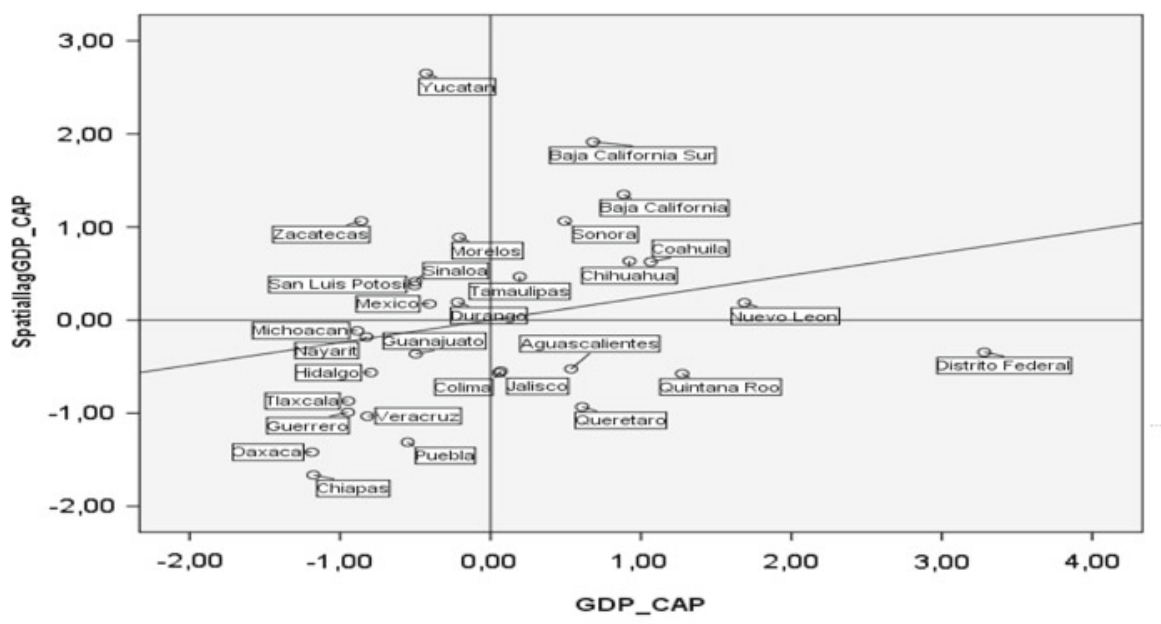

Moran $\mathrm{I}=0.184$, $\mathrm{p}$-value $=0.027$

Fig. 2 Moran scatter plots and Moran I statistic; GDP per capita; 1988 and 1998

0 otherwise. The second order contiguity assumption envisages a larger geographical reach, including states from the first order contiguity assumption as well as their neighbouring states. The gravity-like specification that spatial effects can potentially arise between all regions in a country links the negative distance decay effect to inter-regional distances in a continuous fashion. With this specification, we define the $w_{\mathrm{ij}}$ 's as the inverse distance between the states, whereby we measure interregional distances as the number of kilometres between the capital cities of the states. 
Table 4 Intra- and inter-regional growth effects from agglomeration and FDI

\begin{tabular}{llll}
\hline & Cont_1 & Cont_2 & Distance \\
\hline Initial GDP & $-0.04(0.01) \mathrm{a}$ & $-0.04(0.01) \mathrm{a}$ & $-0.05(0.012) \mathrm{a}$ \\
Man density & $0.008(0.002) \mathrm{a}$ & $0.007(0.002) \mathrm{a}$ & $0.009(0.0022) \mathrm{a}$ \\
Pop density & $-0.016(0.0025) \mathrm{a}$ & $-0.015(0.0024) \mathrm{a}$ & $-0.016(0.003) \mathrm{a}$ \\
FDIflows/GDP & $0.002(0.015)$ & $0.003(0.015)$ & $0.008(0.016)$ \\
Maquiladora*Borderdummy & $0.004(0.0014) \mathrm{a}$ & $0.004(0.0015) \mathrm{b}$ & $0.004(0.0015) \mathrm{b}$ \\
Forman & $-0.003(0.0012) \mathrm{c}$ & $-0.0023(0.0013) \mathrm{c}$ & $-0.004(0.001) \mathrm{a}$ \\
Spatial variables & & & \\
Manufacturing & $0.006(0.007)$ & $-0.001(0.006)$ & $0.013(0.023)$ \\
Population & $0.019(0.0010) \mathrm{b}$ & $0.023(0.009) \mathrm{b}$ & $0.044(0.020) \mathrm{b}$ \\
FDIflows/Pib & $0.003(0.0012) \mathrm{a}$ & $0.003(0.001) \mathrm{a}$ & $-0.0003(0.0015)$ \\
Forman & $-0.007(0.002) \mathrm{a}$ & $-0.007(0.002) \mathrm{a}$ & $-0.017(0.007) \mathrm{b}$ \\
$R^{2}$ & 0.77 & 0.76 & 0.76 \\
$N$ & 90 & 90 & 90
\end{tabular}

Estimated standard errors in parentheses; $a, b$ and $c$ indicate significance levels at 1, 5 and 10\%. Cont_1 indicates distance matrix based on first-order contiguity assumption, Cont_2 indicates distance matrix based on second-order contiguity assumption, distance indicates distance matrix based on inverse of inter-regional distance. Inter-regional distance is measured as distance in kilometres between state capital cities. All regressions are FGLS controlling for heteroscedasticity and autocorrelation. Regression models are estimated including the variables school, telephones, agriculture, state expenditure, 1998 dummy and School*border dummy

The results from estimating regression model (2) are presented in Table 4. Importantly, the estimated effect of the intra-regional agglomeration and FDI variables is robust to the inclusion of the spatially weighted variables. The exception to this is the variable capturing the overall regional growth effect from inward FDI flows. As for the spatial growth effects from agglomeration and FDI, the estimated effect of spatially weighted regional manufacturing size is insignificant in all three estimations, suggesting there is no inter-regional dimension to agglomeration economies from this source. In contrast, the estimated effect of the spatially weighted regional population variable is significant and positive in all three estimations, indicating the presence of positive spatial agglomeration economies from this source. An explanation for the presence of such positive spatial effects is that knowledge spillovers are not confined within regions, as indicated for instance by evidence on the geography of knowledge spillovers in the EU (Greunz 2003; Rodriguez-Pose and Crescenzi 2008). Alternatively, the estimated positive spatial growth effect from regional population size may capture the presence of a market access effect. According to this interpretation, regional growth is enhanced when firms in a region have relatively easy access to large markets in other regions close by (see e.g. Graham 2007; Rice et al. 2006).

Next, the findings indicate that regional FDI is also linked to inter-regional growth effects. The estimated positive effect of the share of inward FDI in regional GDP indicates that this type of capital investment generates positive effects across regions. At the same time, the estimated spatial growth effect of the regional presence of 
manufacturing FDI is negative. We see two possible explanations for this latter finding. It may be the case that negative externalities that arise from the presence of foreign manufacturing firms spill over across regions. ${ }^{15}$ This would be the case if the upward pressure on regional input prices applies to multi-regional input markets. Alternatively, it may be the case that the estimated negative effect captures a process whereby FDI in a given region draws away investment from other regions. The literature on growth effects from public infrastructure investment shows that such investment in a given region can have a negative effect on growth in other regions, when this investment in regional infrastructure draws away investment flows from these other regions (see Boarnet 1998; Sloboda and Yao 2008). In a similar fashion, it may be the case that regions with a high level of regional FDI in manufacturing attract investment from other regions, which would show up as an estimated negative spatial growth effect in our analysis. ${ }^{16}$

Finally, we try to assess to what extent the spatial growth effects from agglomeration and regional FDI explain the overall spatiality of the regional growth process. To do this, we re-estimate regression model 2, replacing the spatial agglomeration and FDI variables with the spatially lagged initial regional GDP per capita variable. We estimate this alternative regression model for all three spatial decay specifications separately. From these regressions, we obtain the estimated growth effect of the spatially lagged initial GDP per capita variable, which we interpret as representing the spatiality of the regional growth process (see Magrini 2004). We then regress this estimated effect on the spatial agglomeration and FDI variables. The adjusted $R^{2}$ of these regressions can then be interpreted as an indication of the degree to which the spatial effects from agglomeration and FDI explain the spatiality of the regional growth process.

The findings from the second stage regressions are presented in Table 5. The adjusted $R^{2}$ ranges between 50 and $65 \%$, indicating that the combined effect of agglomeration and regional FDI constitutes an important component of the overall spatiality of regional growth in Mexico. Therefore, although the spatial spillover

Table 5 Importance of spatial growth effects of agglomeration and FDI

\begin{tabular}{lccc}
\hline Spatial variables & Cont_1 & Cont_2 & Distance \\
\hline Population & $0.008(0.0009) \mathrm{a}$ & $0.0077(0.0008) \mathrm{a}$ & $0.03(0.003) \mathrm{a}$ \\
FDIflows/GDP & $0.0004(0.0002) \mathrm{b}$ & $0.0003(0.0001) \mathrm{a}$ & $0.0011(0.0001) \mathrm{a}$ \\
Forman & $-0.0018(0.0004) \mathrm{a}$ & $-0.0018(0.0004) \mathrm{a}$ & $-0.0013(0.0006) \mathrm{a}$ \\
Adj. $R^{2}$ & 0.53 & 0.52 & 0.65 \\
\hline
\end{tabular}

Dependent variable is estimated growth effect of spatially lagged initial GDP per capita

Cont_1 first-order contiguity assumption, Cont_2 second-order contiguity assumption, Distance distance decay effect based on inter-regional distances, $a$ and $b$ significance levels of 1 and $5 \%$

\footnotetext{
15 Driffield et al. 2004 for instance also present evidence of negative spatial FDI externalities between UK regions.

16 We did experiment in preliminary estimations with a spatially adjusted regional Maquiladora variable. In all estimations, the effect of this variable was insignificant, suggesting that the growth effect from regional Maquiladora FDI is of an intra-regional character.
} 
effects from these two phenomena do not explain the entire spatiality of the regional growth process, these findings clearly serve to further underline the importance of agglomeration and FDI as drivers of regional growth.

\section{Summary and policy implications}

Following the introduction of economic liberalisation and trade promotion in Mexico in the late 1980s, the Mexican economy has experienced structural changes with clear spatial dimensions. An important spatial dimension has been the development of new agglomerations of economic activity in the states that share a border with the US. As a result, the geographical distribution of economic activity in Mexico is now characterised by the existence of a limited number of production centres in the north and the centre of the country. Furthermore, the growing levels of inward FDI have also shown a tendency to concentrate in these agglomerations of economic activity. In combination, these developments suggest that agglomeration and regional FDI are likely to have played an important role as drivers of regional growth in Mexico in the last two decades, a hypothesis that we test empirically in this paper via the estimation of conditional convergence growth regressions.

The main empirical findings of our analysis can be summarised as follows. First of all, the evidence indicates the presence of significant conditional convergence among Mexican regions. Second, both agglomeration and regional FDI have played an important role as drivers of regional growth. Not only do we identify significant growth effects from these two phenomena, but also we find that they both appear to generate positive as well as negative growth effects. Looking at agglomeration economies, the findings contain evidence of the occurrence of positive agglomeration economies in the form of a positive growth effect of density of regional manufacturing and negative agglomeration economies indicated by the negative growth effect of density of total regional economic activity. As for growth effects from regional FDI, the findings indicate a positive effect from total regional FDI flows. At the same time, the level of foreign participation in regional manufacturing is negatively associated with regional growth, indicating the presence of negative FDI spillovers. This negative effect may constitute only a short run effect, however. In addition, there is a separate positive growth effect from the large presence of Maquiladora FDI in the border states.

Third, our findings also identify inter-regional growth effects from agglomeration and regional FDI. In particular, the results suggest the presence of positive inter-regional agglomeration economies linked to total regional economic activity, negative spatial spillovers linked to the level of foreign participation in regional manufacturing and positive growth effects from aggregate regional FDI flows. In extension of this, we also present novel evidence that these spatial effects from agglomeration and FDI represent a major component of the overall spatiality of the regional growth process in Mexico.

Our findings have several implications for policies that aim to stimulate regional growth. Overall, the confirmation that both agglomeration and FDI generate growth effects indicates that regional governments can stimulate regional growth via policies on regional FDI and agglomeration. Having said this, the possibilities to do so are likely 
to be constrained in several ways. First of all, an important part of the growth effects from agglomeration and FDI occur via the generation of externalities. Compared to growth effects from "traditional" regional inputs of capital and labour, externality effects are much more difficult to identify and are far less understood, suggesting that policymaking to influence these regional externalities will be more challenging.

Furthermore, regional development policies need to be designed under the recognition that growth effects from these phenomena may be of a positive or negative nature. For instance, the presence of negative FDI spillovers at the intra-regional level indicates that regional governments will need to ascertain why these negative effects occur and design policies to counteract these negative externalities. The contrasting finding of the existence of positive agglomeration economies from manufacturing and negative externalities linked to total regional economic activity shows that difficult questions concerning the required level of specialisation of regional economic activity and the optimal size and density level of total regional activity will also need to be addressed.

Second, there is the issue to what extent individual regional governments can implement efficient policies that are successful in influencing the location pattern of manufacturing activity and regional inward FDI. The implication of the occurrence of the structural changes in the economic environment that have made the US the new main destination market is that regional policymaking will have to be performed within the context of the broad locational readjustments that the Mexican economy has experienced. This means that regional governments of states that are not located in proximity to the US will find it more difficult to promote new manufacturing activity, given the strong locational advantage of the border states. A government of a state located further away from the US border can try to attract new FDI firms and/or promote the development of indigenous economic activity, but such efforts are very likely to require costly additional measures and compensation. Also, the feature that FDI firms are attracted to those regions in Mexico that contain agglomerations of economic activity suggests the presence of a process of cumulative causation, whereby agglomeration and FDI work together to further geographically concentrate economic activity. Of course, if the ongoing level of geographical concentration in the border states starts to generate substantial congestion-related negative agglomeration economies which counteract the original locational advantage of these states, other states will become more attractive as viable alternative locations.

Finally, the finding that growth effects from agglomeration and FDI transcend regional borders indicates that regional development policies require multi-regional implementation and coordination. For instance, our findings indicate that a state that is actively engaged in the attraction of new FDI firms is very likely to miss out on (part of) the positive effects that these firms generate, as these effects materialise across geographical space. In a similar fashion, the finding that agglomeration economies that are linked to total regional economic activity also transcend regional borders indicates that it is likely that there are important differences between the private and societal economic returns of regional policymaking. Clearly, in these cases, multi-regional and perhaps also federal coordination is required. The identification of this feature is particularly important for a country like Mexico, where regional development policies are 
usually the sole responsibility of individual regional governments. As our findings on the inter-regional growth effects from agglomeration and FDI suggest, multi-regional policymaking will be required to deal with the positive and negative growth effects from these two phenomena.

\section{Appendix}

See Tables 6, 7 and 8.

Table 6 Variables and data-sources

\begin{tabular}{|c|c|c|}
\hline Variable & Definition & Data-source \\
\hline School & $\begin{array}{l}\text { Average years of schooling regional } \\
\text { economic active population older } \\
\text { than } 15 \text { years }\end{array}$ & Provided by Inegi \\
\hline Border & $\begin{array}{l}\text { Dummy for northern states sharing } \\
\text { border with US }\end{array}$ & \\
\hline Border*schooling & Border*Schooling & \\
\hline Telephones & Telephones/100 persons & $\begin{array}{l}1985 \text { (Chiquiar 2005); } 1993 \text { and } \\
1998 \text { Annuario de Estadisticas } \\
\text { Estatal, various years }\end{array}$ \\
\hline Agriculture & $\begin{array}{l}\text { Share of Agriculture in Regional } \\
\text { GDP }\end{array}$ & $\begin{array}{l}1985 \text { (Chiquiar 2005); } 1993 \text { and } \\
1998 \text { provided by Inegi }\end{array}$ \\
\hline State exp & $\begin{array}{l}\text { Share of state government } \\
\text { expenditure in regional GDP }\end{array}$ & $\begin{array}{l}1985 \text { (Chiquiar 2005); } 1993 \text { and } \\
1998 \text { provided by Inegi }\end{array}$ \\
\hline Dummy 1998 & $\begin{array}{l}\text { Dummy variable to capture change in } \\
\text { growth regime }\end{array}$ & See Fig. 1 \\
\hline Manufacturing & Number of manufacturing employees & Economic census 1988, 1933, 1998 \\
\hline Population & Number of inhabitants & Economic census 1988, 1933, 1998 \\
\hline Man density & $\begin{array}{l}\sum u \frac{\text { (employeesman sector)_county }}{\text { (squarekilometers)_county }} \\
u=\frac{\text { (employeesman sector)_county }}{\text { (employeesman sector)_state }}\end{array}$ & Economic census 1988, 1993, 1998 \\
\hline Pop density & $\begin{array}{l}\sum w \frac{\text { (population)_county }}{(\text { squarekilometers)_county }} \\
w=\frac{\text { (population)_county }}{\text { (population)_state }}\end{array}$ & Economic census 1988, 1993, 1998 \\
\hline FDI flows/GDP & $\begin{array}{l}\text { Share of total FDI flows in regional } \\
\text { GDP }\end{array}$ & $\begin{array}{l}\text { Economic census } 1988,1933,1998 \\
\text { and data provided by Inegi }\end{array}$ \\
\hline Maquiladora*Border & $\begin{array}{l}\text { Border*share maquiladora } \\
\text { employees in regional } \\
\text { manufacturing }\end{array}$ & $\begin{array}{l}\text { Sistemas de Cuentas Nacionales de } \\
\text { Mexico. INEGI, various years }\end{array}$ \\
\hline FOR & $\begin{array}{l}\text { Share employees working for FDI in } \\
\text { total regional manufacturing } \\
\text { employees }\end{array}$ & Unpublished data, provided by Inegi \\
\hline
\end{tabular}

Manufacturing density and population density are corrected for differences in density scores across municipalities within states. We calculate the density scores at the municipality level, and then sum these scores using the share of the municipalities in state level manufacturing employment or population as weight 
Table 7 Correlation matrix independent variables

\begin{tabular}{|c|c|c|c|c|c|c|c|c|c|c|c|}
\hline & School & Tel & Agri & Statexp & Manemp & Pop & Densman & Denspop & For & FDI/PIB & Bor-Maqui \\
\hline School & 1.00 & & & & & & & & & & \\
\hline Tel & 0.78 & 1.00 & & & & & & & & & \\
\hline Agri & -0.51 & -0.46 & 1.00 & & & & & & & & \\
\hline Statexp & 0.40 & 0.63 & -0.21 & 1.00 & & & & & & & \\
\hline Manemp & 0.38 & 0.40 & -0.40 & 0.33 & 1.00 & & & & & & \\
\hline Pop & 0.13 & 0.26 & -0.25 & 0.41 & 0.70 & 1.00 & & & & & \\
\hline Densman & 0.42 & 0.70 & -0.26 & 0.76 & 0.36 & 0.46 & 1.00 & & & & \\
\hline Denspop & 0.45 & 0.62 & -0.42 & 0.65 & 0.58 & 0.79 & 0.79 & 1.00 & & & \\
\hline For & 0.48 & 0.58 & -0.29 & 0.72 & 0.37 & 0.23 & 0.39 & 0.38 & 1.00 & & \\
\hline FDI/PIB & 0.09 & 0.27 & -0.05 & 0.007 & -0.16 & -0.06 & 0.14 & 0.07 & -0.02 & 1.00 & \\
\hline Bor-Maqui & 0.33 & 0.23 & -0.11 & 0.11 & 0.32 & 0.06 & 0.02 & 0.08 & 0.30 & 0.01 & 1.00 \\
\hline
\end{tabular}

Table 8 Summary statistics

\begin{tabular}{lrlcr}
\hline Variable & Mean & SD & Min & Max \\
\hline School & 1.91 & 0.164 & 1.43 & 2.28 \\
Border*schooling & 0.32 & 0.75 & 0 & 2.28 \\
Telephones & 2.10 & 0.54 & 0.72 & 3.51 \\
Agriculture & -2.42 & 0.69 & -4.60 & -1.20 \\
State exp & 0.20 & 0.08 & 0.10 & 0.40 \\
Manufacturing & 2.39 & 0.11 & 2.13 & 2.57 \\
Population & 14.57 & 0.81 & 12.67 & 16.38 \\
Man density & 2.92 & 2.11 & -2.25 & 8.96 \\
Pop density & 5.46 & 1.59 & 0.99 & 9.01 \\
FOR & -2.27 & 1.71 & -9.56 & 1.29 \\
FDI flows/PIB & -4.19 & 1.92 & -9.82 & 1.09 \\
Maquiladora*Border & 1.26 & 2.99 & 0 & 9.53 \\
\hline
\end{tabular}

Acknowledgments We would like to thank Gilles Duranton and two anonymous referees for their valuable and constructive comments. The usual disclaimers apply and all remaining errors are ours.

Open Access This article is distributed under the terms of the Creative Commons Attribution Noncommercial License which permits any noncommercial use, distribution, and reproduction in any medium, provided the original author(s) and source are credited.

\section{References}

Aitken BJ, Harrison AE (1999) Do domestic firms benefit from direct foreign investment? Evidence from Venezuela. Am Econ Rev 89:605-618

Aitken B, Hanson G, Harrison AE (1997) Spillovers, foreign investment and export behaviour. J Int Econ 43:103-132 
Anselin L (1988) Spatial econometrics: methods and models. Kluwer, Dordrecht

Aroca P, Bosch M, Maloney WF (2005) Spatial dimensions of trade liberalization and economic convergence: Mexico 1985-2002. World Bank Econ Rev 19:345-378

Barro R (1991) Economic growth in a cross section of countries. Q J Econ 106:407-443

Barro R, Sala-i-Martin X (1995) Economic growth. MIT Press, London

Blalock G, Gertler PJ (2008) Welfare gains from foreign direct investment through technology transfer to local suppliers. J Int Econ 74:402-421

Blomström M, Persson H (1983) Foreign investment and spillover efficiency in an underdeveloped economy: Evidence from the Mexican manufacturing industry. World Dev 11:493-501

Blomström M, Wolff E (1994) Multinational corporations and productivity convergence in Mexico. In: Baumol W, Nelson R, Wolff E (eds) Convergence of productivity: cross-national studies and historical evidence. Oxford University Press, Oxford

Blomström M, Kokko A (1998) Multinational corporations and spillovers. J Econ Surv 12:1-31

Boarnet MG (1998) Spillovers and the locational effects of public infrastructure. J Reg Sci 38:381-400

Bode E (2004) The spatial pattern of localised R\&D spillovers: An empirical investigation for Germany. J Econ Geogr 4:43-64

Cardenas E (1996) La politica economica en Mexico: 1950-1994. Fondo de Cultura Economica, El Colegio de Mexico, Mexico, DF

Caves RE (2007) Multinational enterprise and economic analysis. Cambridge University Press, Cambridge

Chiquiar D (2005) Why Mexico's regional income divergence broke down. J Dev Econ 77:257-275

Ciccone A (2002) Agglomeration effects in Europe. Eur Econ Rev 46:213-227

Ciccone A, Hall RE (1996) Productivity and the density of economic activity. Am Econ Rev 86:54-70

Driffield N (2004) Regional policy and spillovers from FDI in the UK. Ann Reg Sci 38:579-594

Driffield N, Munday M, Roberts A (2004) Inward investment, transaction linkages and productivity spillovers. Pap Reg Sci 83(4):699-722

Duranton G, Puga D (2004) Micro-foundations of urban agglomeration economies. In: Henderson VJ, Thisse JF (eds) Handbook of urban and regional economics, vol 4. North-Holland, Amsterdam

Eberts RW, McMillen D (1999) Agglomeration economies and public infrastructure. In: Cheshire P, Mill ES (eds) Handbook of urban and regional economics, vol 3. North-Holland, Amsterdam

Esquivel G, Messmacher M (2002) Sources of regional (non) convergence in Mexico. IBRD, Chief Economic office for Latin America, Washington, DC

Faber B (2007) Towards the spatial pattern of sectoral adjustment to trade liberalization. Growth Change 38:567-595

Feenstra RC, Hanson GH (1997) Foreign direct investment and relative wages: evidence from Mexico's maquiladora. J Int Econ 42:371-393

Girma S, Wakelin K (2007) Local productivity spillovers from foreign direct investment in the UK electronics industry. Reg Sci Urban Econ 37:399-412

Glaeser EL, Gottlieb JD (2009) The wealth of cities: agglomeration economies and spatial equilibrium in the United States. NBER Working Paper Series, no. 14806. National Bureau of Economic Research, Cambridge

Gonzalez Rivas M (2007) The effects of trade openness on regional inequality in Mexico. Ann Reg Sci 41:545-561

Graham DJ (2007) Identifying urbanisation and localisation externalities in manufacturing and service industries. Pap Reg Sci 88:63-84

Greunz L (2003) Geographically and technologically mediated knowledge spillovers between European regions. Ann Reg Sci 37:657-680

Hanson G (1997) Increasing returns, trade and the regional structure of wages. Econ J 107:113-133

Hanson G (1998a) North American economic integration and industry location. Oxf Rev Econ Policy $14: 30-44$

Hanson G (1998b) Regional adjustment to trade liberalisation. Reg Sci Urban Econ 28:419-444

Hanson G (2001) Scale economies and the geographic concentration of industry. J Econ Geogr 1:255-276

Harris R, Kravtsova V (2009) In search of “W”, SERC Discussion Paper Series, no. 17, Spatial Economics Research Centre, School of Economics, London

Hausman J (1978) Specification tests in econometrics. Econometrica 46:1251-1271

Henderson VJ (2007) Understanding knowledge spillovers. Reg Sci Urban Econ 37:497-508

Henderson VJ, Shalizi Z, Venables AJ (2001) Geography and development. J Econ Geogr 1:81-105 
INEGI (2000) Sistema de cuentas nacionales de Mexico: La produccion, salarios, empleo y productividad de la industria Maquiladora. Instituto Nacional de Estadistica y Geografia, Aguascalientes

Jordaan JA (2005) Determinants of FDI-induced externalities: New empirical evidence for Mexican manufacturing industries. World Development 33:2103-2118

Jordaan JA (2008a) State characteristics and the locational choice of foreign direct investment: Evidence from regional FDI in Mexico 1989-2006. Growth Change 39:389-413

Jordaan JA (2008b) Regional foreign participation and externalities: New empirical evidence from Mexican regions. Environ Plann A 40:2948-2969

Jordaan JA (2008c) Intra- and inter-industry externalities from foreign direct investment in the Mexican manufacturing sector: New evidence from Mexican regions. World Dev 36:2838-2854

Jordaan JA (2009) Foreign direct investment, agglomeration and externalities. Ashgate, Surrey

Jordaan JA (2010) Cross-sectional estimation of FDI spillovers when FDI is endogenous: OLS and IV estimates for Mexican manufacturing industries. Appl Econ [First published on 01 March 2010 (iFirst)]

Jordaan JA, Sanchez-Reaza J (2006) Trade liberalisation and location: empirical evidence for Mexican manufacturing industries 1980-2003. Rev Reg Stud 36:279-303

Juan Ramon VH, Rivera-Batiz LA (1996) Regional growth in Mexico 1973-1883. IMF Working Paper no WP/96/92. International Monetary Fund, Washington

Krugman P, Livas-Elizondo R (1996) Trade policy and the third world metropolis. J Dev Econ 49:137-150

Li X, Lui X (2005) Foreign direct investment and economic growth: an increasingly endogenous relationship. World Dev 33:393-407

Lipsey RE (2004) Home- and host country effects of foreign direct investment. In: Baldwin RE, Winters AL (eds) Challenges to globalisation. Chicago University Press, Chicago

Magrini S (2004) Regional (di)convergence. In: Henderson VJ, Thisse JF (eds) Handbook of urban and regional economics, vol 4. North-Holland, Amsterdam

Marshall A (1890) The principles of economics. Macmillen, London

Martin R (1999) The new 'geographical' turn in economics: some critical reflections. Cambridge J Econ 23:63-91

Moomaw RL (1988) Agglomeration economies: localisation or urbanisation? J Urban Stud 25:150-161

Pacheco-Lopez P(2005) Foreign direct investment, exports and imports in Mexico. World Econ 28:1157-1172

Parr JB (2002) Agglomeration economies: ambiguities and confusions. Environ Plann A 34:717-731

Pritchett L (2001) Where has all the education gone? World Bank Econ Rev 43:303-334

Ramirez MD (2003) Mexico under NAFTA: a critical assessment. Q Rev Econ Finance 43:863-892

Rice P, Venables AJ, Patacchini E (2006) Spatial determinants of productivity: analysis for the regions of Great Britain. Reg Scid Urban Econ 36:727-752

Rodriguez-Oreggia E (2005) Regional disparities and determinants of growth in Mexico. Ann Reg Sci 39:207-220

Rodriguez-Oreggia E (2007) Winners and losers of regional growth in Mexico and their dynamics. Investig Econ 259:43-62

Rodriguez-Oreggia E, Rodriguez-Pose A (2004) Regional returns to public investment policies in Mexico. World Dev 39(9):1545-1562

Rodriguez-Pose A, Sanchez-Reaza J (2002) The impact of trade liberalisation on regional disparities in Mexico. Growth Change 33:72-90

Rodríguez-Pose A, Sánchez-Reaza J (2005) Economic polarization through trade: trade liberalization and regional growth in Mexico. In: Kanbur R, Venables AJ (eds) Spatial inequality and development. Oxford University Press, Oxford

Rodriguez-Pose A, Crescenzi R (2008) Research and development spillovers, innovation systems, and the genesis of regional growth in Europe. Reg Stud 42:51-67

Rosenthal S, Strange W (2004) Evidence of the nature and sources of agglomeration economies. In: Henderson VJ, Thisse JF (eds) Handbook of urban and regional economics, vol 4. North-Holland, Amsterdam

Schnellenbach J, Döring T (2006) What do we know about geographical knowledge spillovers? A survey of the literature. Reg Stud 40:375-395

Sjöholm F (1999) Productivity growth in Indonesia: the role of regional characteristics and foreign investment. Econ Dev Cult Change 47:559-584

Sloboda B, Yao V (2008) Interstate spillovers of private capital and public spending. Ann Reg Sci 42:505-518 
Storper M, Venables AJ (2004) Buzz: face-to-face contact and the urban economy. J Econ Geogr 4:351-370 ten Kate A (1992) Trade liberalisation and economic stabilisation in Mexico: lessons of experience. World Dev 20:659-672

UNCTAD (2007) World Investment Report 2007: transnational corporations, extractive industries and development. United Nations Conference on Tariffs and Trade, Geneva 